\title{
Prevalence of dental caries in children and adolescents with type 1 diabetes: a systematic review and meta-analysis
}

\author{
Yan Wang, Lin Xing ${ }^{*}$, Hui Yu and LiJuan Zhao
}

\begin{abstract}
Background: Dental caries and type 1 diabetes are responsible for a large burden of global disease; however, the exact prevalence of dental caries among children and adolescents with type 1 diabetes remains controversial, and no quantitative meta-analysis exists. Thus, we performed a meta-analysis to evaluate the prevalence of dental caries among children and adolescents with type 1 diabetes.

Methods: We performed a systematic search strategy using PubMed, EMBASE and China National Knowledge Infrastructure for relevant studies investigating the prevalence of dental caries in children and adolescents with type 1 diabetes from July 1971 until December 2018. The pooled prevalence with 95\% confidence intervals (95\%Cls) and subgroup analyses were calculated using a random effects model.

Results: After screening 358 non-duplicated articles, a total of 10 articles involving 538 individuals were included. The overall prevalence of dental caries among children and adolescents with type 1 diabetes was 67\% (95\% Cl: $\left.0.56-0.77 \% ; P^{2}=83 \%\right)$. The prevalence was highest in South America (84\%) and lowest in diabetic patients with good metabolic control (47\%).

Conclusions: The prevalence of dental caries was high among children and adolescents with type 1 diabetes. Screening and preventive treatment should be included in dental clinical routines for diabetic children and adolescents, especially in those with poor metabolic control.
\end{abstract}

Keywords: Adolescent, Caries, Children, Diabetes, Meta-analysis, Prevalence

\section{Introduction}

Type 1 diabetes mellitus is a chronic autoimmune disease characterized by the destruction of pancreatic beta cells and insulin deficiency, and affects over half a million children worldwide [1]. The prevalence and incidence of type 1 diabetes is increasing, especially in European countries [2]. Numerous epidemiological studies have reported that type 1 diabetes increases the risk for cardiovascular diseases [3], kidney disease [4] and cognitive decline [5] in children and adolescents. Additionally, a growing number of studies indicate an underlying link between type 1 diabetes and oral complications, including periodontal diseases [6] and dental caries [7]. Dental caries is the most common chronic infectious disease, and has posed an

\footnotetext{
* Correspondence: xinglin1985@126.com

Yan Tai Stomatological Hospital, No. 142 Beida Street Zhifu District, Yantai 264008, Shandong, China
}

(c) The Author(s). 2019 Open Access This article is distributed under the terms of the Creative Commons Attribution 4.0 International License (http://creativecommons.org/licenses/by/4.0/), which permits unrestricted use, distribution, and reproduction in any medium, provided you give appropriate credit to the original author(s) and the source, provide a link to the Creative Commons license, and indicate if changes were made. The Creative Commons Public Domain Dedication waiver (http://creativecommons.org/publicdomain/zero/1.0/) applies to the data made available in this article, unless otherwise stated. children [8]. Additionally, it has become a major concern as it can begin early in life, progress rapidly in those individuals who are at high risk, and often goes untreated [9]. Its consequences can lead to poor food intake, poor school performance, and mental health problems, which can affect the quality of life of the child's family, and impact significant social and economic burdens as well [10].

Clinical caries are diagnosed by the DMFT index $(\mathrm{D}=$ dentine caries lesion; $\mathrm{M}=$ missing due to caries; $\mathrm{F}$ = filled; $\mathrm{T}=$ tooth), according to World Health Organization (WHO) criteria [11]. Although dental caries have been declining, a national survey in the United States between 2001 and 2012 showed that approximately 37\% of children aged $2-8$ years and $60 \%$ of adolescents aged $12-19$ years had experienced dental caries in their primary teeth [12]. One goal of the WHO is to reduce the DMFT index in 
2020, and in particular, the D component, in high-risk groups [13].

Screening and preventive treatment are necessary to avoid dental caries before they become incurable in the high-risk population. However, the exact prevalence of dental caries remains controversial in children and adolescents with type 1 diabetes [14-17], especially in those with poor metabolic control [18]. Previous studies reported that the prevalence of dental caries in children and adolescents varies between $36 \%$ in Iran [19] and 92\% in Chile [20]. Moreover, several studies have showed that a higher prevalence was observed in diabetic adolescents with poor metabolic control compared to patients with good metabolic control $[18,21]$. Therefore, we performed a meta-analysis using data available from access reports to estimate the overall prevalence of dental caries in children and adolescents with type 1 diabetes.

\section{Methods}

\section{Search strategy}

This meta-analysis was conducted and reported according to the Preferred Reporting Items for Systematic Reviews and Meta-Analysis statement (Additional file 2) [22]. Major databases including PubMed, EMBASE and China National Knowledge Infrastructure were searched from inception to 28 December 2018 for terms that contained the keywords "dental caries" and "type 1 diabetes" in multiple combinations. The search strategy was conducted without language restrictions (Additional file 1). We also manually reviewed the reference lists of all studies of interest to identify additional studies.

\section{Study eligibility}

The inclusion criteria were as follows: 1) cross-sectional studies or the first evaluation of longitudinal studies; 2) studies that were conducted among children (under 12 years old) and adolescents (12-18 years old); 3 ) information about prevalence estimates; 4 ) dental caries were diagnosed by both primary and permanent definitions (dmft/DMFT/DFS/dfs $>0$ ), according to the WHO criteria; and 5) the study included participants with a validated diagnosis of type 1 diabetes. To assess the quality of articles and to avoid bias, case reports, review articles, case-control studies, letters to the editor, or studies that were conducted on young adults were excluded. However, we included conference abstracts that provided available information about the prevalence of dental caries in children and adolescents with type 1 diabetes. To ensure accuracy and completeness, two co-authors (Y.W. and L.X.) independently reviewed and selected relevant studies, and achieved an inter-rater reliability (Kappa $=0.68)$. Any differences between the two reviewers were resolved by consensus and a final list of articles was compiled.

\section{Data extraction and quality assessment}

The data were extracted from the list of articles described above. If multiple studies were performed on the same population, the study with the most complete and updated dataset was retained. The extracted information include the name of the first author, year of publication, country, sample size, sex, age, metabolic control of type 1 diabetes, and the prevalence of dental caries. The quality of each study was assessed using the modified Newcastle-Ottawa Quality assessment scale (NOS) [23]. Studies with a NOS $\geq 3$ were regarded as high quality (Additional file 3).

\section{Statistical analysis}

All statistical analyses were undertaken using the R software, version 3.5.2. The prevalence of dental caries was extracted from individual studies and combined using the generic inverse variance method of Der Simonian and Laird random-effects.

model. The heterogeneity of effect size among studies was quantified using $I^{2}$ [24]. The influence analysis was performed by removing one study at a time to evaluate whether the pool estimates could have been altered by a single study. Subgroup analyses were conducted by mean age, continent and metabolic control of type 1 diabetes. For all comparisons, the pooled prevalence with 95\% CI were reported. The Egger's test and funnel plots were conducted to assess the existence of publication bias. A $p<0.05$ was considered statistically significant.

\section{Results}

\section{Literature search and characteristics of the included studies}

We identified 488 potentially eligible articles, including one article from the reference lists of articles of interest. After the removal of duplicates and screening the titles or abstracts, a total of 83 full-text articles were reviewed, of which 73 articles were excluded. Overall, 10 articles (538 individuals) were included in our final meta-analysis [18-21, 25-30]. A summary of the literature review and study selection process is shown in Fig. 1. Studies were published from 1997 to 2017 with sample sizes ranging from 25 to 87 . Among the included articles, four were conducted in Asia, three were performed in Europe, two were conducted in South America and one was conducted in North America. The evaluation of dental caries was conducted through clinical examinations, in accordance with WHO criteria (including DMFT, dmft, DFS, dfs). Information about the metabolic control of type 1 diabetes was provided in three articles.

The methodological quality of studies was based on the modified NOS scale, in which studies could receive up to 5 possible points. One study received 4 points, six studies received 3 points, and three studies received 2 


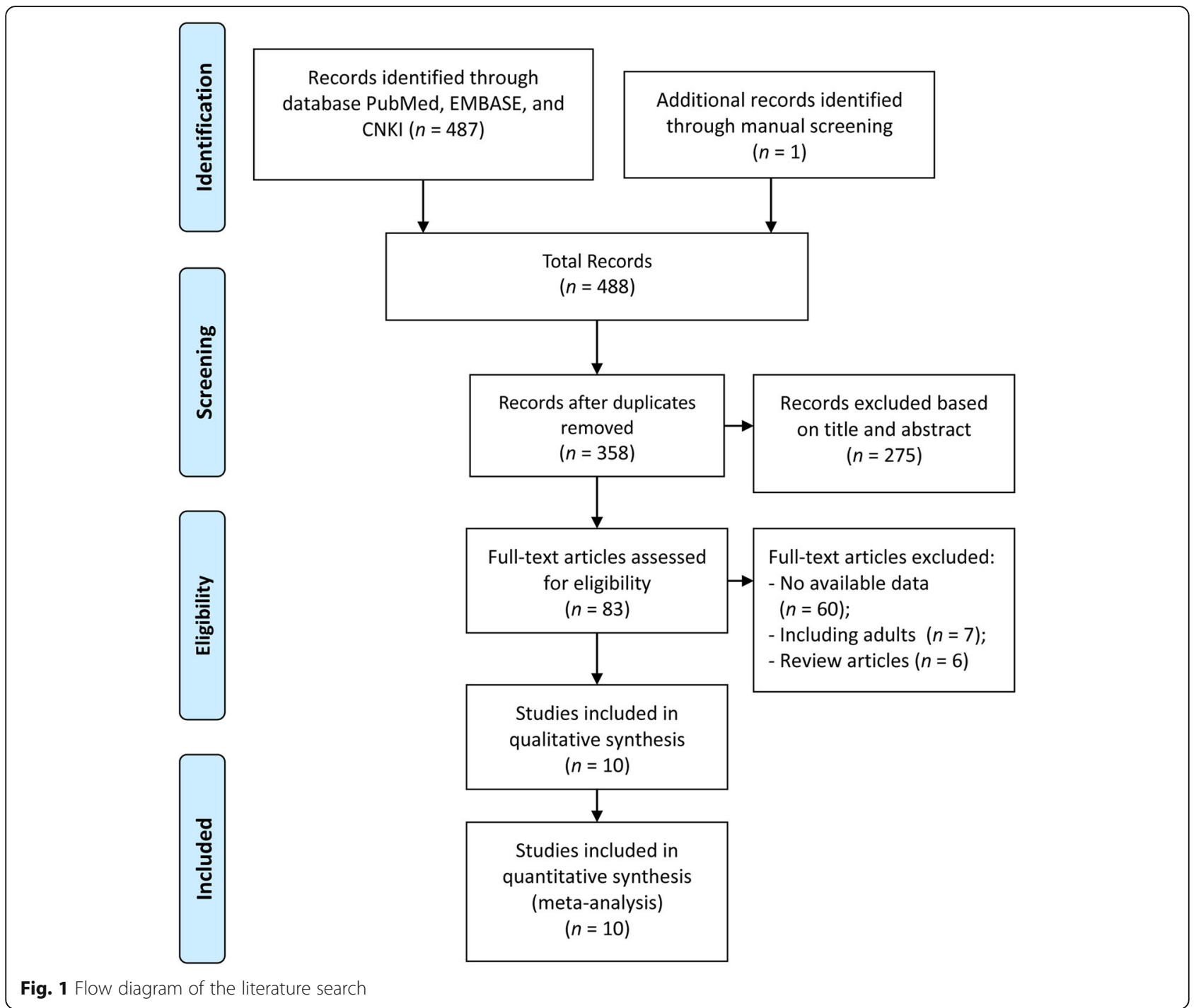

points. The detailed characteristics and quality assessments of those studies are shown in Table 1 and Additional file 4 , respectively.

\section{Quantitative synthesis}

The overall prevalence of dental caries among children and adolescents with type 1 diabetes was $67 \%$ (95\% CI: $0.56-0.77 \% ; I^{2}=83 \%$ ) based on the random effects model. The maximum and minimum prevalence of dental caries were observed in Chile (92\%) and Iran (36\%), respectively (Fig. 2). Five studies provided data of the mean DMFT/dmft. The pooled mean (SD) DMFT/dmft was 5.7 (3.6).

\section{Subgroup and influence analysis}

Sub-analyses were performed to explore whether heterogeneity might be caused by variations in geographical region or the metabolic control of type 1 diabetes, and whether such differences may also affect the pooled prevalence estimate. We first conducted a sub-analysis among geographical region (Fig. 3). The prevalence of dental caries in South America (84\%) was higher than in studies conducted in Asia (67\%), North America (64\%) and Europe (57\%). The next sub-analysis aimed to distinguish between good and poor metabolic control of type 1 diabetes (Fig. 4). The prevalence of dental caries in children and bad adolescents with type 1 diabetes with good metabolic control (47\%) was lower than that in children and adolescents with type 1 diabetes with poor metabolic control (66\%). Finally, when stratified by mean age ( $\leq 10$ vs $>10$ years old), the prevalence of dental caries was higher in children younger than 10 years of age (80\%), compared to children or adolescents older than 10 years of age (56\%) (Fig. 5). Sensitivity analyses were performed by omitting one study at a time to judge the robustness of the pooled effect. The pooled 
Table 1 Characteristics of included studies

\begin{tabular}{|c|c|c|c|c|c|c|c|c|c|}
\hline Authors, year & Country & $\begin{array}{l}\text { Age } \\
\text { (years) }^{a}\end{array}$ & $\begin{array}{l}\text { Gender } \\
(\mathrm{M} \%)\end{array}$ & $\begin{array}{l}\text { Total Sample } \\
\text { size }\end{array}$ & $\begin{array}{l}\text { Dental caries } \\
\text { measurement }\end{array}$ & $\begin{array}{l}\text { Sample size of type } 1 \\
\text { diabetes }\end{array}$ & $\begin{array}{l}\text { Sample size } \\
\text { of dental } \\
\text { caries }\end{array}$ & $\begin{array}{l}\text { Mean (SD) } \\
\text { DMFT/dmft }\end{array}$ & $\begin{array}{l}\text { Prevalence of } \\
\text { dental caries }\end{array}$ \\
\hline Lai et al., 2017 & Sweden & $\begin{array}{l}12.11 \pm \\
2.77\end{array}$ & $\begin{array}{l}M / F \\
(48.53 \%)\end{array}$ & $\begin{array}{l}204(136 \\
\text { healthy } \\
\text { control) }\end{array}$ & DMFT & $\begin{array}{l}68 \text { GMC (Hb1acミ7.5): } \\
20 \text { BMC (Hb1ac > 7.5): } 48\end{array}$ & $\begin{array}{l}28 \text { GMC: } 6 \\
\text { BMC: } 22\end{array}$ & NR & $\begin{array}{l}\text { 41.18\% } \\
\text { GMC: } 30 \% \\
\text { BMC: } 45.83 \%\end{array}$ \\
\hline $\begin{array}{l}\text { Abeuova et al., } \\
2017\end{array}$ & Kazakhstan & $<18$ & NR & 60 & DMFT & 60 & 47 & $8.7(2.2)$ & $70 \%$ \\
\hline Ofilada, 2015 & Philippines & $10-18$ & $\begin{array}{l}M / F \\
(44 \%)\end{array}$ & 25 & DMFT & 25 & 18 & 4.6 & $72 \%$ \\
\hline $\begin{array}{l}\text { Carneiro et al., } \\
2015\end{array}$ & Brazil & $10.7 \pm 2.6$ & $\begin{array}{l}M / F \\
(32.18 \%)\end{array}$ & 87 & $\mathrm{DMFT}+\mathrm{dmft}$ & $\begin{array}{l}87 \mathrm{GMC}(\mathrm{Hb} 1 \mathrm{ac} \leqq 8): 11 \\
\text { BMC (Hb1ac }>8): 76\end{array}$ & $\begin{array}{l}69 \text { GMC: } 6 \\
\text { BMC: } 61\end{array}$ & $\begin{array}{l}\mathrm{GMC}=0.8 \\
\mathrm{BMC}=2.4\end{array}$ & $\begin{array}{l}\text { 79.31\% GMC: } \\
54.55 \% \text { BMC: } \\
80.26 \%\end{array}$ \\
\hline $\begin{array}{l}\text { Ofilada et al., } \\
2013\end{array}$ & Philippines & $1-15$ & $M / F$ & 28 & DMFT & 28 & 22 & 8.2 & $78.58 \%$ \\
\hline $\begin{array}{l}\text { Miranda et al., } \\
2013\end{array}$ & Chile & $<15$ & $\begin{array}{l}M / F \\
(68.00 \%)\end{array}$ & 25 & $\mathrm{dmft}$ & 25 & 23 & NR & $92.00 \%$ \\
\hline $\begin{array}{l}\text { Gomez-Diaz } \\
\text { et al., } 2012\end{array}$ & Mexico & $11.6 \pm 3.2$ & $\begin{array}{l}M / F \\
(52.17 \%)\end{array}$ & 69 & DMFT & $\begin{array}{l}69 \text { GMC (Hb1acミ7): } 11 \\
\text { BMC (Hb1ac > 7): } 76\end{array}$ & $\begin{array}{l}44 \text { GMC: } 13 \\
\text { BMC: } 31\end{array}$ & NR & $\begin{array}{l}\text { 63.77\% GMC: } \\
56.52 \% \text { BMC: } \\
67.39 \%\end{array}$ \\
\hline $\begin{array}{l}\text { Alavi et al., } \\
2006\end{array}$ & Iran & $\begin{array}{l}11.72 \pm \\
3.36\end{array}$ & $\begin{array}{l}\mathrm{M} / \mathrm{F} \\
(44.00 \%)\end{array}$ & 50 & DMFT & 50 & 18 & $9.6(4.6)$ & $36 \%$ \\
\hline $\begin{array}{l}\text { Twetman et al., } \\
2002\end{array}$ & Sweden & $11.2 \pm 3.0$ & $\begin{array}{l}M / F \\
(50.00 \%)\end{array}$ & 64 & $\mathrm{DFS}+\mathrm{dfs}$ & 64 & 41 & NR & $64.06 \%$ \\
\hline $\begin{array}{l}\text { Karjalainen } \\
\text { et al., } 1997\end{array}$ & Finlan & $14.8 \pm 1.6$ & $\begin{array}{l}M / F \\
(51.61 \%)\end{array}$ & 62 & DFS & 62 & 41 & NR & $66.13 \%$ \\
\hline
\end{tabular}

GMC/BMC, good or bad metabolic controlled type 1 diabetes; NR not report, DMFT+dmft decayed, missing or filled teeth index for permanent and primary teeth, $D F S+d f s$ decayed or filled surfaces for permanent and primary teeth

${ }^{a}$ Age was described as mean \pm standard deviation or range

prevalence of dental caries ranged from 65 to $70 \%$ (Fig. 6). We performed another sensitivity analysis and only retained the studies in which DMFT was used as the diagnostic method for caries, and the pooled prevalence of dental caries was $62 \%$.

\section{Assessment of publication bias}

We investigated the potential of publication bias using funnel plots and the Egger's test. Neither methods (funnel plots, Fig. 7; and Egger's test, $P=0.17$ ) showed publication bias in our studies.

\section{Discussion}

Several studies have reported the prevalence of caries among children and adolescents with type1 diabetes; however, studies have shown a high degree of variability in dental caries prevalence among such populations. Thus, this meta-analysis was performed to examine the

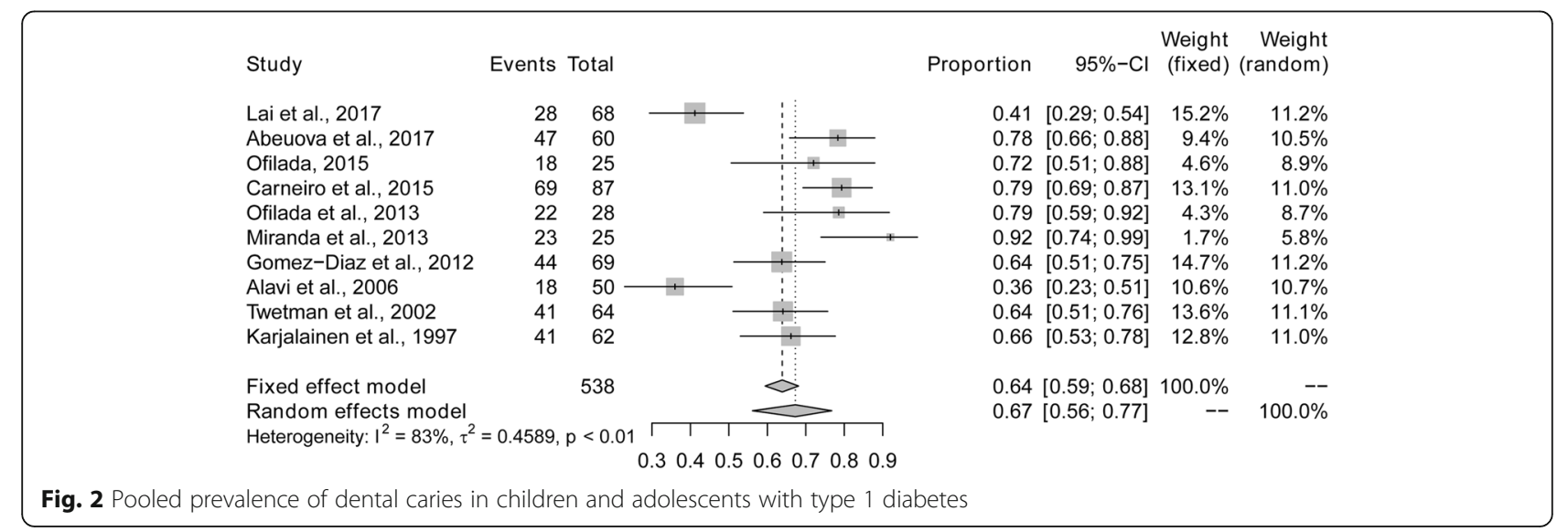




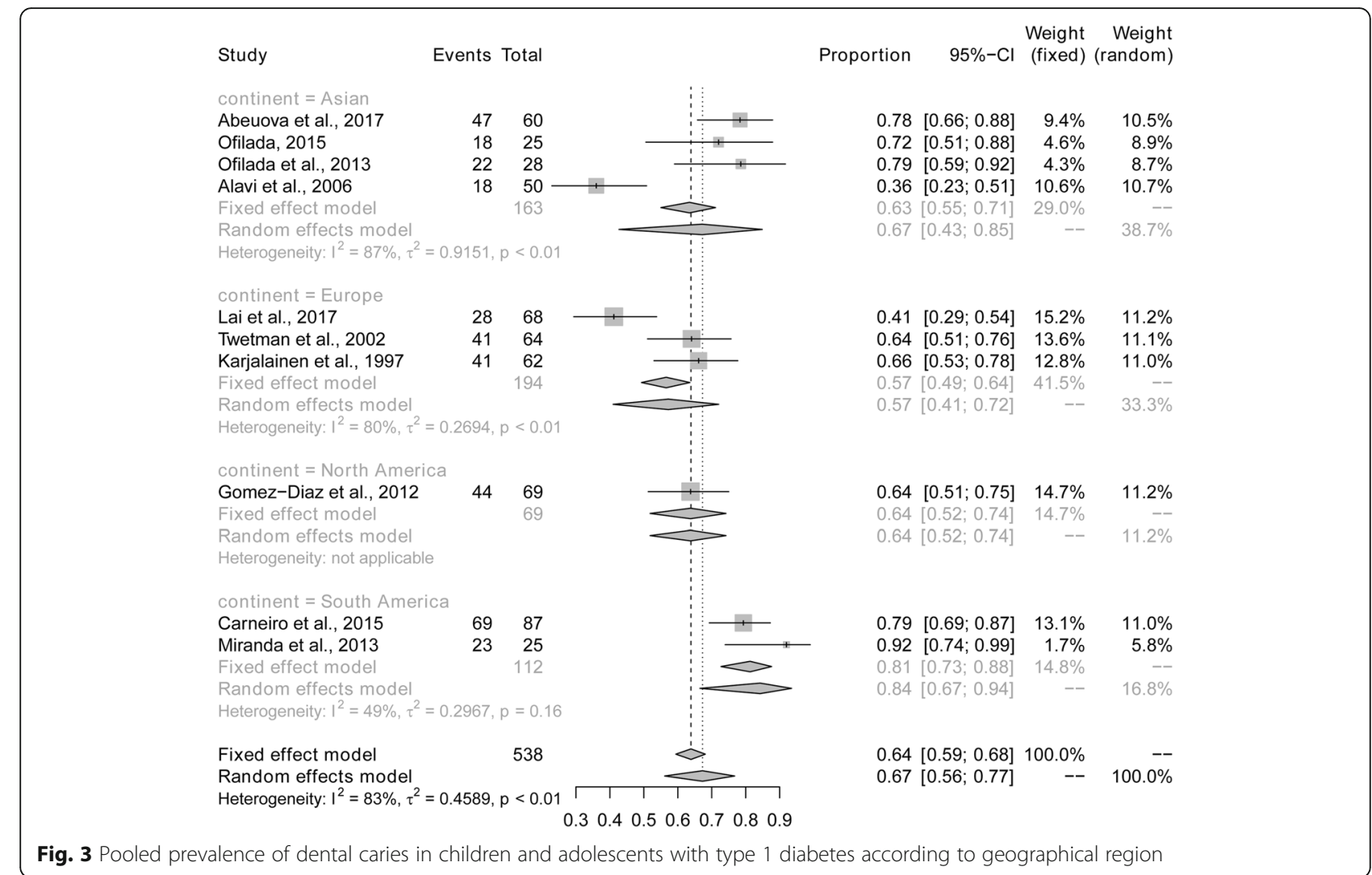

prevalence of dental caries among children and adolescents with type 1 diabetes. Our results showed that approximately $67 \%$ of children and adolescents with type 1 diabetes had dental caries, and the mean DMFT values is 5.7. In a US National Health and Nutrition Examination Survey (NHANES), approximately $37 \%$ of children aged 2-8 years and $58 \%$ of adolescents had experienced dental caries in primary teeth [31]. Another national survey in Greece showed that the mean $\mathrm{dmft} / \mathrm{DMFT}$ values were $1.77,2.05$, and 3.19 in 5,12 and 15-year-old children, respectively [32]. Our study highlighted that the prevalence and severity of dental caries among children and adolescents with type 1 diabetes was higher than that in the general population.

The heterogeneity of dental caries might be explained, in part, by different population characteristics, ethnic backgrounds, diet [33], duration of diabetes, and treatment $[34,35]$. In agreement with our results, a study

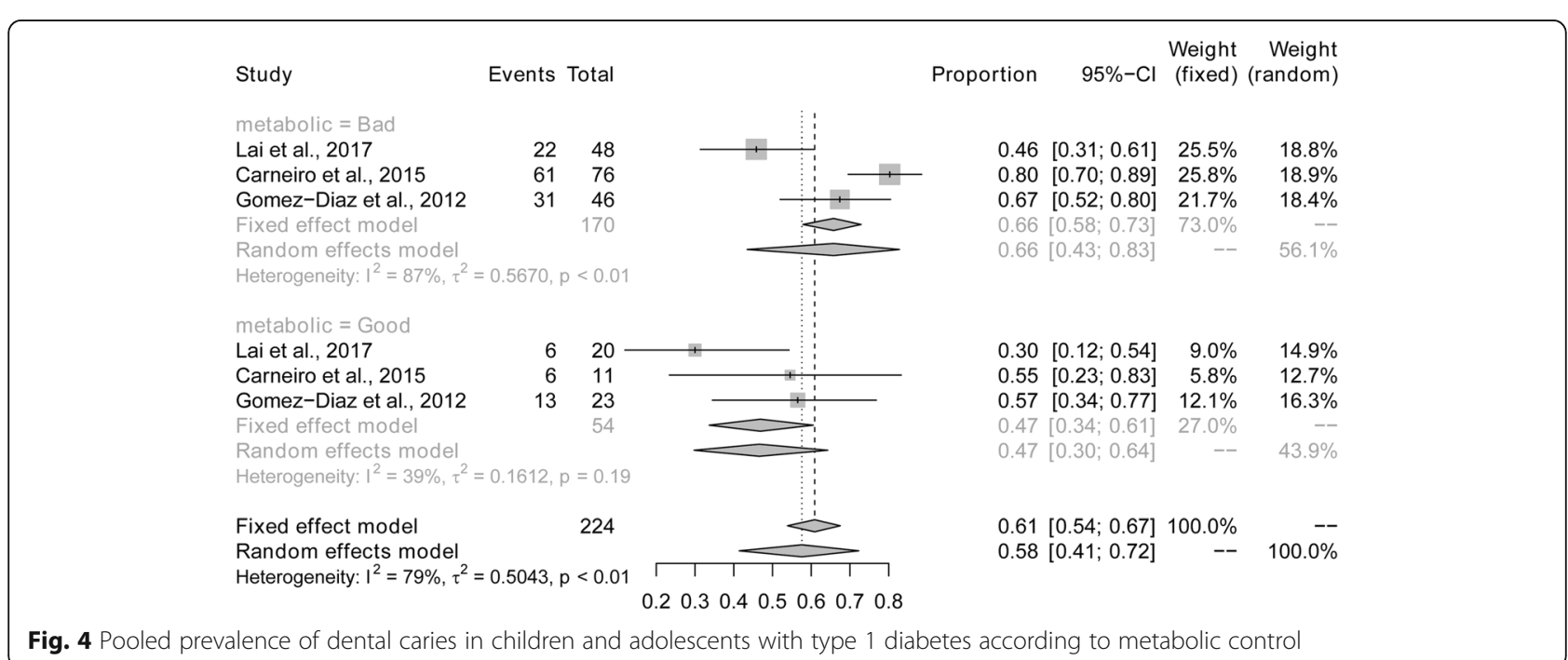




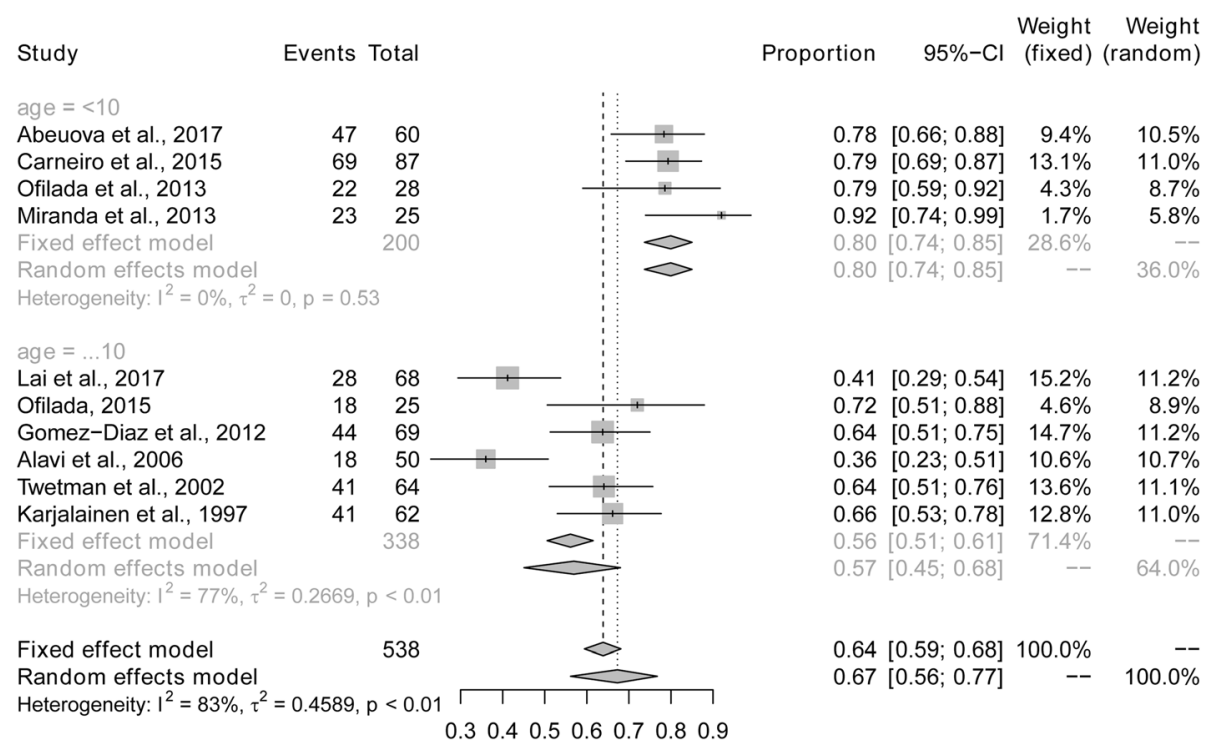

Fig. 5 Pooled prevalence of dental caries in children and adolescents with type 1 diabetes according to mean age

conducted in Mangalore city showed that the prevalence of dental caries was highest in the 5-7 year age group, compared to that of $8-10$ and $11-13$ year age groups [36]. The higher prevalence of dental caries in younger children might be attributable to the reduction in the number of primary teeth with age due to normal exfoliation. NHANES showed that the prevalence of dental caries among children was 1.5 times higher in Hispanic children, compared to non-Hispanic white and Asian children [31]. Interestingly, a similar result was found in our study, in which the prevalence of dental caries in South American patients was nearly 1.2, 1.3 and 1.5 times higher than that in Asian, North American and European patients, respectively. One research indicated that those patients with a longer duration of type 1 diabetes had higher mean DMFT indexes [34].

As a multifactorial disease, the high prevalence of dental caries in patients with type 1 diabetes, and especially in those with poor metabolic control, might be dependent on the interaction of genetic factors, oral cariogenic bacteria, food intake and oral hygiene. First, insulin deficiency might cause degenerative changes in the salivary glands and lead to a reduced salivary flow and salivary buffer capacity. Additionally, the overall dehydration associated with hyperglycemia might decrease the volume of excreted saliva [37]. Second, Alemzadeh et al., found high levels of mutans streptococci and lactobacilli among diabetic subjects, particularly in

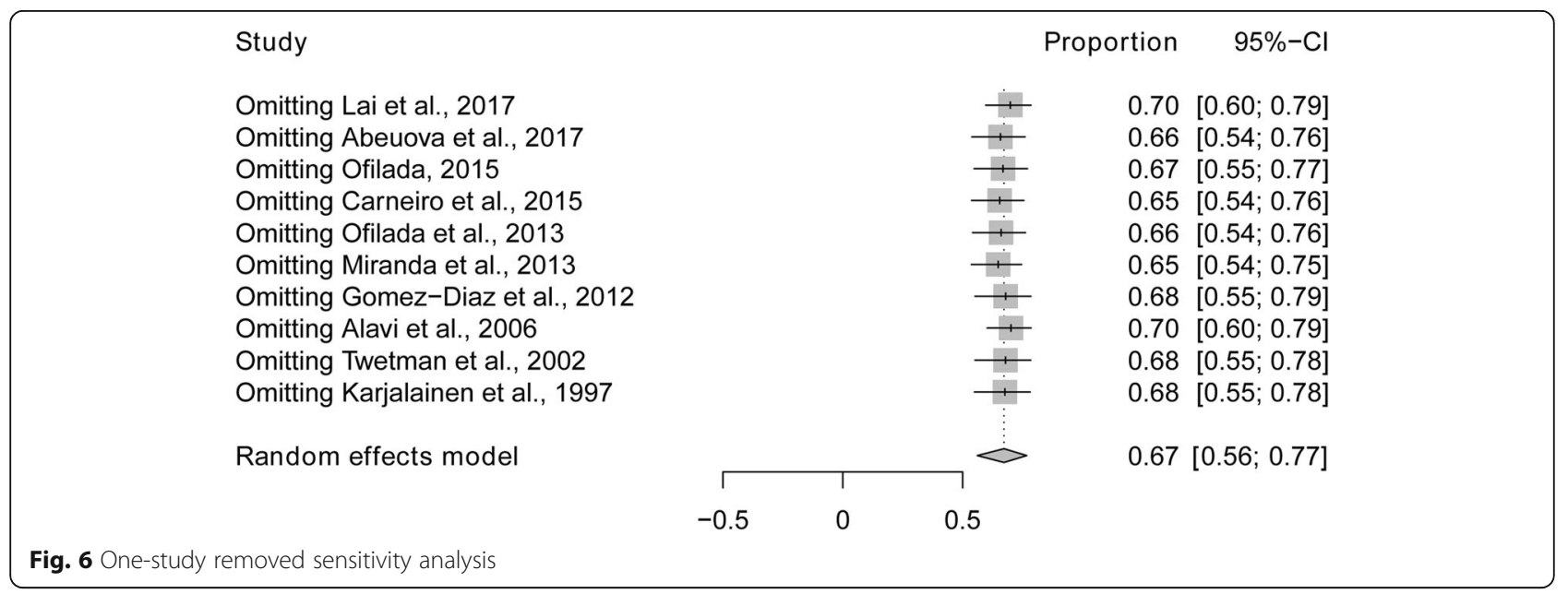




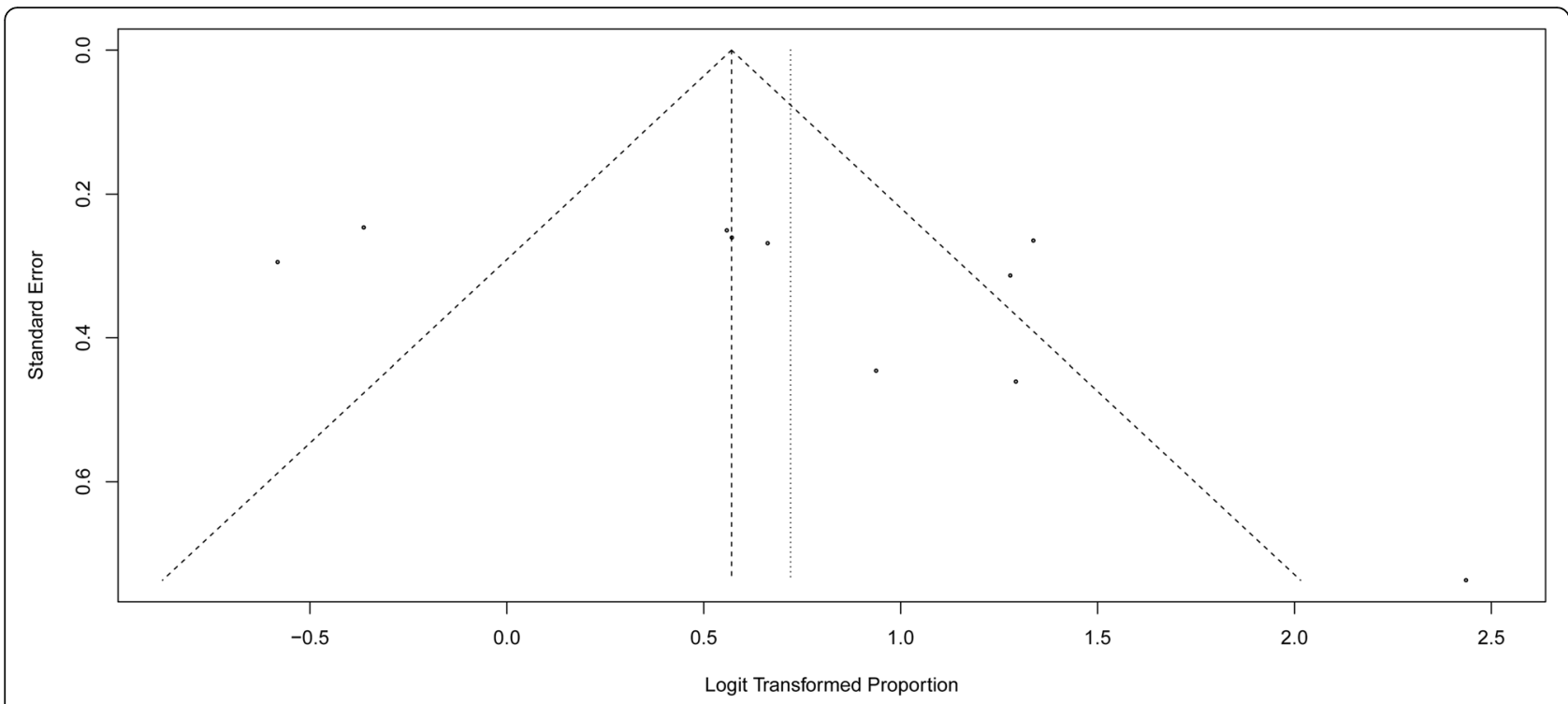

Fig. 7 Funnel plot for all studies

subjects with poor metabolic control [38]. Third, multiple studies showed that a high intake of saturated fat in type 1 diabetic children and adolescents [39-41]. Moreover, consumption of energy dense, low nutrition foods that are characterized by high saturated fat, and low fiber and vegetables have been associated with increased weight gain and obesity, which may lead to dental caries in children $[42,43]$. Fourth, although the oral hygiene knowledge and habits of children with type 1 diabetes appear to be superior to healthy individuals $[44,45]$, poor quality diets might negatively affect oral health through their effects on immune function and glycemic control in children and adolescents with type 1 diabetes [46].

Previous review articles mainly assessed the severity of dental caries in diabetic children and adolescents with type 1 diabetes $[1,47]$, while our study, investigated the prevalence of dental caries in those populations for the first time. Therefore, this study provided a reference that can be used for clinical consideration, as well as epidemiological and clinical research. Nevertheless, this meta-analysis had several limitations. The heterogeneity was high, although part of which could be explained by geographical region and metabolic control status. Moreover, due to the incomplete data contained in original articles, some factors that greatly influence dental caries, including sex, diabetes mellitus duration and insulin treatment duration, could not be analyzed. Our data captured only 10 studies with small sample sizes, which emphasizes the need for more comprehensive studies worldwide.

Early recognition and intervention can prevent the increased deterioration of dental caries and the potential negative impacts on patients' quality of life [48]. To decrease the prevalence of dental caries, it is critical for children and adolescents with type 1 diabetes to be screened for early signs of dental caries, and to be examined annually for oral health. Moreover, good metabolic control could help reduce and control the prevalence of dental caries among such populations.

\section{Conclusion}

There is a high global prevalence of dental caries among children and adolescents with type 1 diabetes. Thus, health-care personnel and clinicians should screen and provide preventive treatments during dental clinical routine for diabetic children and adolescents. Further research on the risk of dental caries among children and adolescents with type 1 diabetes is necessary to ensure optimal oral health for such vulnerable patients.

\section{Additional files}

Additional file 1: Search strategy. (PDF $72 \mathrm{~kb}$ )

Additional file 2: PRISMA checklist. (DOC $67 \mathrm{~kb}$ )

Additional file 3: Modified Newcastle-Ottawa risk of bias scoring guide. (DOCX $12 \mathrm{~kb}$ )

Additional file 4: Quality assessment of included studies. (DOCX $15 \mathrm{~kb}$ )

\section{Abbreviations}

DMFT: Decayed, Missing, Filled index; NOS: Newcastle-Ottawa Quality assessment scale; PRISMA; PRISMA: Preferred reporting items for systematic review and meta-analysis; WHO: World Health Organization

Acknowledgements Not applicable. 


\section{Authors' contributions}

YW, LX and HYM determined the search strategy. YW and LX conducted the selection of relevant studies and data extraction separately. YW and LX evaluated the quality of each study independently. YW, LX and HYM did the analyses and outcomes. YW, LX, HYM and LJZ drafted the manuscript. All authors revised and approved the final version of the manuscript.

\section{Funding}

There was no funding for this review.

\section{Availability of data and materials}

The datasets used and/or analysed during the current study are available from the corresponding author on reasonable request.

\section{Ethics approval and consent to participate}

Not applicable.

\section{Consent for publication}

Not applicable.

\section{Competing interests}

The authors declare that they have no competing interests.

\section{Received: 13 February 2019 Accepted: 30 August 2019}

\section{Published online: 14 September 2019}

\section{References}

1. Novotna M, Podzimek S, Broukal Z, Lencova E, Duskova J. Periodontal diseases and dental caries in children with type 1 diabetes mellitus. Mediat Inflamm. 2015:2015:379626.

2. Fox DA, Islam N, Sutherland J, Reimer K, Amed S. Type 1 diabetes incidence and prevalence trends in a cohort of Canadian children and youth. Pediatr Diabetes. 2018;19(3):501-5.

3. Ahmadizar F, Fazeli Farsani S, Souverein PC, van der Vorst MM, de Boer A, Maitland-van der Zee AH. Cardiovascular medication use and cardiovascular disease in children and adolescents with type 1 diabetes: a populationbased cohort study. Pediatr Diabetes. 2016;17(6):433-40.

4. Helve J, Sund R, Arffman M, Harjutsalo V. Incidence of End-Stage Renal Disease in Patients With Type 1 Diabetes. Diabetes Care. 2018;41(3):434-9.

5. Tonoli C, Heyman E, Roelands B, Pattyn N, Buyse L, Piacentini MF, Berthoin S, Meeusen R. Type 1 diabetes-associated cognitive decline: a meta-analysis and update of the current literature. J Diabetes. 2014;6(6):499-513.

6. Khader YS, Dauod AS, El-Qaderi SS, Alkafajei A, Batayha WQ. Periodonta status of diabetics compared with nondiabetics: a meta-analysis. J Diabetes Complicat. 2006;20(1):59-68.

7. Miko S, Ambrus S, Sahafian S, Dinya E, Tamas G, Albrecht M. Dental caries and adolescents with type 1 diabetes. Br Dent J. 2010;208(6):E12.

8. Colak H, Dulgergil CT, Dalli M, Hamidi MM. Early childhood caries update: a review of causes, diagnoses, and treatments. J Nat Sci Biol Med. 2013;4(1): 29-38.

9. Grindefjord M, Dahllof G, Modeer T. Caries development in children from 2. 5 to 3.5 years of age: a longitudinal study. Caries Res. 1995;29(6):449-54.

10. Ganesh A, Muthu MS, Mohan A, Kirubakaran R. Prevalence of early childhood caries in India - a systematic review. Indian J Pediatr. 2018;86(3): 276-86

11. World Health Organization. Oral Health Surveys: Basic Methods (5th edn.). Geneva: World Health Organization; 2013.

12. Dye BA, Thornton-Evans G, Li X, lafolla TJ. Dental caries and sealant prevalence in children and adolescents in the United States, 2011-2012. NCHS Data Brief. 2015;(191):1-8. https://www.cdc.gov/nchs/data/databriefs/ db191.pdf.

13. Hobdell M, Petersen PE, Clarkson J, Johnson N. Global goals for oral health 2020. Int Dent J. 2003;53(5):285-8

14. Coelho A, Paula A, Mota M, Laranjo M, Abrantes M, Carrilho F, Ferreira M, Silva M, Botelho F, Carrilho E. Dental caries and bacterial load in saliva and dental biofilm of type 1 diabetics on continuous subcutaneous insulin infusion. J Appl Oral Sci. 2018;26:e20170500.

15. Rafatjou R, Razavi Z, Tayebi S, Khalili M, Farhadian M. Dental health status and hygiene in children and adolescents with type 1 diabetes mellitus. Res Health Sci. 2016;16(3):122-6.
16. Akpata ES, Alomari Q, Mojiminiyi OA, Al-Sanae H. Caries experience among children with type 1 diabetes in Kuwait. Pediatr Dent. 2012:34(7):468-72.

17. Miralles L, Silvestre FJ, Hernandez-Mijares A, Bautista D, Llambes F, Grau D. Dental caries in type 1 diabetics: influence of systemic factors of the disease upon the development of dental caries. Med Oral Patol Oral Cir Bucal. 2006; 11(3):E256-60

18. Carneiro VL, Fraiz FC, Ferreira Fde M, Pintarelli TP, Oliveira AC, Boguszewski MC. The influence of glycemic control on the oral health of children and adolescents with diabetes mellitus type 1. Arch Endocrinol Metab. 2015; 59(6):535-40.

19. Alavi AA, Amirhakimi E, Karami B. The prevalence of dental caries in 5 - 18year-old insulin-dependent diabetics of Fars Province, southern Iran. Arch Iran Med. 2006:9(3):254-60.

20. Miranda OX, Troncoso PJ, Rodríguez SC, Aravena TP, Jiménez Del RP. Dental caries and hygiene oral index in children with diabetes mellitus type 1. Rev Chil Pediatr. 2013;84(5):527-31

21. Lai S, Cagetti MG, Cocco F, Cossellu D, Meloni G, Campus G, Lingstrom P. Evaluation of the difference in caries experience in diabetic and nondiabetic children-a case control study. PLoS One. 2017:12(11):e0188451.

22. Moher D, Liberati A, Tetzlaff J, Altman DG. Preferred reporting items for systematic reviews and meta-analyses: the PRISMA statement. BMJ (Clinical research ed). 2009:339:b2535.

23. Stang A. Critical evaluation of the Newcastle-Ottawa scale for the assessment of the quality of nonrandomized studies in meta-analyses. Eur J Epidemiol. 2010;25(9):603-5.

24. Higgins JP, Thompson SG. Quantifying heterogeneity in a meta-analysis. Stat Med. 2002;21(11):1539-58.

25. Abeuova B, Tuleutaeyva S, Ashirbekova Z. Dental health in children with diabetes mellitus. Eur J Pediatr. 2017;176(11):1479.

26. Ofilada EJL. Oral health status of children attending a summer camp for diabetes children. J ASEAN Federation Endocrine Societies. 2015;30(2):138-41.

27. Ofilada EJL, Jimeno CA. A survey on the barriers to dental care among individuals with type 1 diabetes. Phillippine J Intern Med. 2013;51:2.

28. Gomez-Diaz RA, Ramirez-Soriano E, Tanus Hajj J, Bautista Cruz E, Jimenez Galicia C, Villasis-Keever MA, Aguilar-Salinas CA, Wacher NH. Association between carotid intima-media thickness, buccodental status, and glycemic control in pediatric type 1 diabetes. Pediatr Diabetes. 2012;13(7):552-8.

29. Twetman S, Johansson I, Birkhed D, Nederfors T. Caries incidence in young type 1 diabetes mellitus patients in relation to metabolic control and cariesassociated risk factors. Caries Res. 2002;36(1):31-5.

30. Karjalainen KM, Knuuttila ML, Kaar ML. Relationship between caries and leve of metabolic balance in children and adolescents with insulin-dependent diabetes mellitus. Caries Res. 1997;31(1):13-8.

31. Dye BA, Thornton-Evans G, Li X, lafolla TJ. Dental caries and sealant prevalence in children and adolescents in the United States, 2011-2012; 2015

32. Oulis C, Tsinidou K, Vadiakas G, Mamai-Homata E, Polychronopoulou A, Athanasouli T. Caries prevalence of 5, 12 and 15-year-old Greek children: a national pathfinder survey. Community Dent Health. 2012;29(1):29-32.

33. Siudikiene J, Maciulskiene V, Nedzelskiene I. Dietary and oral hygiene habits in children with type I diabetes mellitus related to dental caries. Stomatologija. 2005;7(2):58-62.

34. Bakhshandeh S, Murtomaa H, Vehkalahti M, Mofid R, Suomalainen K. Dental findings in diabetic adults. Caries Res. 2008;42(1):14-8.

35. Tagelsir A, Cauwels R, Van Aken S, Vanobbergen J, Martens LC. Dental caries and dental care level (restorative index) in children with diabetes mellitus type 1. Int J Paediatr Dent. 2011;21(1):13-22.

36. Sudha P, Bhasin S, Anegundi R. Prevalence of dental caries among 5-13year-old children of Mangalore city. J Ind Soc Pedod Prev Dent. 2005;23(2): 74

37. Rai K, Hegde A, Kamath A, Shetty S. Dental caries and salivary alterations in type I diabetes. J Clin Pediatr Dent. 2011;36(2):181-4.

38. Siudikiene J, Machiulskiene V, Nyvad B, Tenovuo J, Nedzelskiene I. Dental caries and salivary status in children with type 1 diabetes mellitus, related to the metabolic control of the disease. Eur J Oral Sci. 2006;114(1):8-14.

39. Froisland DH, Arsand E, Skarderud F. Improving diabetes care for young people with type 1 diabetes through visual learning on mobile phones: mixed-methods study. J Med Internet Res. 2012:14(4):e111.

40. Schober E, Langergraber B, Rupprecht G, Rami B. Dietary intake of Austrian diabetic children 10 to 14 years of age. J Pediatr Gastroenterol Nutr. 1999. 29(2):144-7. 
41. Overby NC, Flaaten V, Veierod MB, Bergstad I, Margeirsdottir HD, DahlJorgensen K, Andersen LF. Children and adolescents with type 1 diabetes eat a more atherosclerosis-prone diet than healthy control subjects. Diabetologia. 2007:50(2):307-16.

42. Vernarelli JA, Mitchell DC, Hartman TJ, Rolls BJ. Dietary energy density is associated with body weight status and vegetable intake in U.S. children. J Nutr. 2011;141(12):2204-10.

43. Hayden C, Bowler JO, Chambers S, Freeman R, Humphris G, Richards D, Cecil JE. Obesity and dental caries in children: a systematic review and meta-analysis. Community Dent Oral Epidemiol. 2013;41(4):289-308.

44. Vidya K, Shetty P, Anandakrishna L. Oral health and glycosylated hemoglobin among type 1 diabetes children in South India. J Indian Soc Pedod Prev Dent. 2018;36(1):38-42

45. Alves $C$, Brandao M, Andion J, Menezes R. Oral health knowledge and habits in children with type 1 diabetes mellitus. Braz Dent J. 2009;20(1):70-3.

46. Petersen PE, Bourgeois D, Ogawa H, Estupinan-Day S, Ndiaye C. The global burden of oral diseases and risks to oral health. Bull World Health Organ. 2005;83(9):661-9.

47. Sampaio N, Mello S, Alves C. Dental caries-associated risk factors and type 1 diabetes mellitus. Pediatr Endocrinol Diabetes Metab. 2011;17(3):152-7.

48. Abanto J, Paiva SM, Raggio DP, Celiberti P, Aldrigui JM, Bönecker M. The impact of dental caries and trauma in children on family quality of life. Community Dent Oral Epidemiol. 2012;40(4):323-31.

\section{Publisher's Note}

Springer Nature remains neutral with regard to jurisdictional claims in published maps and institutional affiliations.

- fast, convenient online submission

- thorough peer review by experienced researchers in your field

- rapid publication on acceptance

- support for research data, including large and complex data types

- gold Open Access which fosters wider collaboration and increased citations

- maximum visibility for your research: over $100 \mathrm{M}$ website views per year

At $\mathrm{BMC}$, research is always in progress.

Learn more biomedcentral.com/submissions 